\title{
PENENTUAN RAINBOW CONNECTION NUMBER UNTUK AMALGAMASI GRAF LENGKAP DENGAN GRAF RODA
}

\author{
RISYA HAZANI UTARI, LYRA YULIANTI, SYAFRIZAL SY \\ Program Studi S1 Matematika, \\ Fakultas Matematika dan Ilmu Pengetahuan Alam, Universitas Andalas, \\ Kampus UNAND Limau Manis Padang, Indonesia. \\ email : cacautariii@gmail.com
}

Diterima 9 Maret 2019 Direvisi 7 April 2019 Dipublikasikan 7 Mei 2019

\begin{abstract}
Abstrak. Suatu pewarnaan terhadap sisi-sisi di graf $G$ terhubung tak trivial didefinisikan sebagai $c: E(G) \rightarrow\{1,2, \cdots, k\}$ untuk $k \in N$ adalah suatu pewarnaan terhadap sisi-sisi di $G$ sedemikian sehingga setiap sisi yang bertetangga boleh diberi warna yang sama. Banyaknya warna minimal yang diperlukan untuk membuat graf $G$ bersifat rainbow connected disebut dengan rainbow connection number dari $G$, yang dinotasikan dengan $r c(G)$. Penelitian ini menentukan rainbow connection number untuk amalgamasi 2 buah graf lengkap $K_{4}$ dengan 2 buah graf roda $W_{4}$ yang diperoleh dari menggabungkan satu titik pada setiap graf lengkap $K_{4}$ dengan satu titik pusat pada setiap graf roda $W_{4}$.
\end{abstract}

Kata Kunci: Amalgamasi, Graf lengkap $K_{4}$, Graf Roda $W_{4}$, Rainbow Connection Number

\section{Pendahuluan}

Misalkan $G$ adalah graf terhubung tak trivial, didefinisikan $c: E(G) \rightarrow\{1,2, \cdots, k\}$ untuk $k \in N$ adalah suatu pewarnaan terhadap sisi-sisi di $G$ sedemikian sehingga setiap sisi yang bertetangga boleh diberi warna yang sama. Graf $G$ bersifat rainbow connected terhadap pewarnaan $c$ jika untuk setiap $u, v \in V(G)$, terdapat rainbow path antara $u$ dan $v$. Dalam hal ini, pewarnaan $c$ dikatakan sebagai suatu rainbow coloring dari $G$. Banyaknya warna minimal yang diperlukan untuk membuat graf $G$ bersifat rainbow connected disebut dengan rainbow connection number dari $G$, yang dinotasikan dengan $r c(G)$.

Amalgamasi merupakan penggabungkan satu titik dari masing-masing graf menjadi sebuah titik baru yang disebut dengan terminal. Notasi yang digunakan untuk menyatakan operasi amalgamasi adalah "*". Fitriani D dan ANM Salman. [2] mengkaji tentang penentuan rainbow connection number untuk amalgamasi beberapa graf. Dalam tulisan ini akan dibahas tentang rainbow connection number untuk amalgamasi graf lengkap $K_{4}$ dengan graf roda $W_{4}$, yaitu graf $\left(2 K_{4} * 2 W_{4}, v\right)$. 


\section{Tinjauan Teori}

Teorema 2.1. [1] Jika $G$ adalah graf terhubung tak trivial berukuran $m$ yang mempunyai diameter $\operatorname{diam}(G)$, maka

$$
\operatorname{diam}(G) \leq r c(G) \leq \operatorname{src}(G) \leq m .
$$

Teorema 2.2. [1] Misalkan $G$ adalah graf terhubung tak trivial yang berukuran $m$, maka:

(a) $\operatorname{rc}(G)=1$ jika dan hanya jika $G$ adalah graf lengkap,

(b) $\operatorname{rc}(G)=2$ jika dan hanya jika $\operatorname{src}(G)=2$,

(c) $r c(G)=m$ jika dan hanya jika $G$ adalah graf pohon.

\section{Rainbow Connection Number pada Graf $\left(2 K_{4} * 2 W_{4}, v\right)$}

$G \cong\left(2 K_{4} * 2 W_{4}, v\right)$ merupakan graf hasil amalgamasi 2 buah graf lengkap $K_{4}$ dan 2 buah graf roda $W_{4}$ yang diperoleh dari mengamalgamasikan satu titik pada setiap graf lengkap $K_{4}$ yaitu titik $u_{i, 1}$ dimana $1 \leq i \leq 2$ dengan satu titik pusat pada graf roda $W_{4}$ yaitu titik $v_{i, 0}$ dimana $1 \leq i \leq 2$.

Teorema 3.1. Misalkan terdapat graf $G \cong\left(2 K_{4} * 2 W_{4}, v\right)$. Maka rc $(G=3$.

Bukti. Notasikan $\left(K_{4}\right)^{i}$ sebagai graf lengkap $K_{4}$ ke-i dan $\left(W_{4}\right)^{i}$ sebagai graf roda $W_{4}$ ke-i, untuk $i=1,2$.

Karena $\operatorname{diam}(G)=2$ sehingga berdasarkan Teorema 2.1, $r c\left(2 K_{4} * 2 W_{4}, v\right) \geq 2$. Misalkan $r c\left(2 K_{4} * 2 W_{4}, v\right)=2$ dan $c$ adalah rainbow 2-coloring. Diketahui untuk setiap titik $x, y \in V(G)$ dengan panjang lintasan 2, jika diberikan warna pada graf $K_{4}$ adalah 1 , maka apabila pada graf $W_{4}$ diberikan warna 2 , lintasan diantara titik di $\left(K_{4}\right)^{1}$ dengan titik di $\left(K_{4}\right)^{2}$ dan graf $\left(W_{4}\right)^{1}$ dengan graf $\left(W_{4}\right)^{2}$ bukan rainbow path. Jadi haruslah, $r c\left(2 K_{4} * 2 W_{4}, v\right) \geq 3$.

Akan ditunjukkan $r c\left(2 K_{4} * 2 W_{4}, v\right) \leq 3$. Didefinisikan pewarnaan sebagai berikut, dapat dilihat pada Gambar 3 .

$$
\begin{aligned}
c\left(v u_{1,3}\right)=c\left(v u_{2,3}\right)=1 & =c\left(v u_{2,2}\right)=c\left(v u_{2,4}\right)=2 \\
c\left(v u_{1,2}\right) & =c\left(v u_{1,4}\right) \quad=c \\
c\left(u_{1,2} u_{1,3}\right) & =c\left(u_{1,3} u_{1,4}\right)=c\left(u_{1,4} u_{1,2}\right)=3 \\
c\left(u_{2,2} u_{2,3}\right) & =c\left(u_{2,3} u_{2,4}\right)=c\left(u_{2,4} u_{2,2}\right)=3 . \\
c\left(v v_{1,1}\right) & =c\left(v v_{1,3}\right)=c\left(v v_{2,1}\right)=c\left(v v_{2,3}\right)=1 \\
c\left(v v_{1,2}\right) & =c\left(v v_{1,4}\right)=c\left(v v_{2,2}\right)=c\left(v v_{2,4}\right)=2 \\
c\left(v_{1,1} v_{1,2}\right) & =c\left(v_{1,2} v_{1,3}\right)=c\left(v_{1,3} v_{1,4}\right)=c\left(v_{1,4} v_{1,1}\right)=3 \\
c\left(v_{2,1} v_{2,2}\right) & =c\left(v_{2,2} u_{2,3}\right)=c\left(v_{2,3} v_{2,4}\right)=c\left(v_{2,4} v_{2,1}\right)=3 .
\end{aligned}
$$

Diperoleh $r c\left(2 K_{4} * 2 W_{4}, v\right) \leq 3$. Jadi haruslah $r c\left(2 K_{4} * 2 W_{4}, v\right)=3$. 


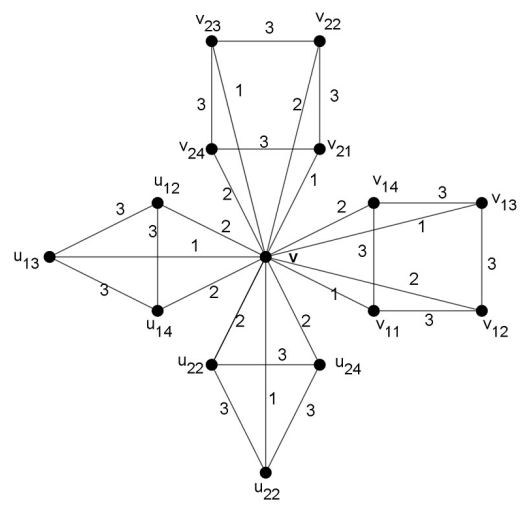

Gambar 1. Rainbow Connection Number pada graf $\left(2 K_{4} * 2 W_{4}, v\right)$

\section{Kesimpulan}

Pada makalah ini telah ditentukan rainbow connection number pada graf $\left(2 K_{4}\right.$ * $\left.2 W_{4}, v\right)$, yaitu $r c\left(2 K_{4} * 2 W_{4}, v\right)=3$.

\section{Ucapan Terima kasih}

Penulis mengucapkan terima kasih kepada bapak Narwen, M.Si, ibu Radhiatul Husna, M.Si, dan bapak Zulakmal, M.Si selaku dosen penguji yang telah memberikan kritik dan saran dalam penulisan makalah ini.

\section{Daftar Pustaka}

[1] Chartrand, G., Kalamazoo, G. L. Johns, S. Valley, and K. A. McKeon. 2006. Rainbow connection in graph. Mathematica Bohemica, 133: $85-89$

[2] Fitriani, D dan A. N. M Salman. 2016. Rainbow connection number of amalgamation of some graphs. AKCE International Journal of Graphs and Combinatorics, 13: 90 - 99 